\title{
A Stimulating Recollection of Chou's Graph Theory in Enzyme Kinetics
}

\author{
Kuo-Chen Chou \\ Gordon Life Science Institute, Boston, MA, USA \\ Email: kcchou@gordonlifescience.org,kcchou38@gmail.com
}

How to cite this paper: Chou, K.-C. (2020). A Stimulating Recollection of Chou's Graph Theory in Enzyme Kinetics. Voice of the Publisher, 6, 161-163.

https://doi.org/10.4236/vp.2020.64018

Received: September 15, 2020

Accepted: November 14, 2020

Published: November 17, 2020

Copyright $\odot 2020$ by author(s) and Scientific Research Publishing Inc.

This work is licensed under the Creative

Commons Attribution International

License (CC BY 4.0).

http://creativecommons.org/licenses/by/4.0

(c) (i) Open Access

\begin{abstract}
In this short review paper, the significant and profound impacts of the Chou's graph theory in enzyme kinetics have been briefly recalled with crystal clear convincingness.
\end{abstract}

\section{Keywords}

Graphic Theory, Enzyme Kinetics, Significant Impacts, Profound Impacts

The first paper introducing the graph theory to enzyme kinetics was published in 1979 [1], which has stimulated a series of follow-up papers (see, e.g., [2]-[18]).

Using graphic approaches to study biological and medical systems can provide an intuitive vision and useful insights for helping analyze complicated relations therein as shown by the eight master pieces of pioneering papers from the then Chairman of Nobel Prize Committee Sture Forsen [19]-[26]. It is indeed both significant and profound by using graphic approaches to study biological and medical systems.

Actually, it has led to a revolution in medicinal chemistry [27] [28].

\section{Conflicts of Interest}

The author declares no conflicts of interest regarding the publication of this paper.

\section{References}

[1] Chou, K.C., Jiang, S.P., Liu, W.M. and Fee, C.H. (1979) Graph Theory of Enzyme Kinetics: 1. Steady-State Reaction System. Scientia Sinica, 22, 341-358.

[2] Zhou, G.Z. (1979) Influence of van der Walls' Force upon Diffusion-Controlled Reaction Rate. Scientia Sinica, 17, 845-858. 
[3] Chou, K.C. and Liu, W.M. (1981) Graphical Rules for Non-Steady State Enzyme Kinetics. Journal of Theoretical Biology, 91, 637-654. https://doi.org/10.1016/0022-5193(81)90215-0

[4] Chou, K.C. (1983) Advances in Graphical Methods of Enzyme Kinetics. Biophysical Chemistry, 17, 51-55. https://doi.org/10.1016/0301-4622(83)87013-6

[5] Chou, K.C. (1989) Graphic Rules in Steady and Non-Steady Enzyme Kinetics. Journal of Biological Chemistry, 264, 12074-12079.

[6] Chou, K.C. (1990) Review: Applications of Graph Theory to Enzyme Kinetics and Protein Folding Kinetics. Steady and Non-Steady State Systems. Biophysical Chemistry, 35, 1-24. https://doi.org/10.1016/0301-4622(90)80056-D

[7] Chou, K.C. (1993) Graphic Rule for Non-Steady-State Enzyme Kinetics and Protein Folding Kinetics. Journal of Mathematical Chemistry, 12, 97-108. https://doi.org/10.1007/BF01164628

[8] Zhang, C.T. and Chou, K.C. (1993) Graphic Analysis of Codon Usage Strategy in 1490 Human Proteins. Journal of Protein Chemistry, 12, 329-335.

https://doi.org/10.1007/BF01028195

[9] Chou, K.C. (2010) Graphic Rule for Drug Metabolism Systems. Current Drug Metabolism, 11, 369-378. https://doi.org/10.2174/138920010791514261

[10] Wu, Z.C., Xiao, X. and Chou, K.C. (2010) 2D-MH: A Web-Server for Generating Graphic Representation of Protein Sequences Based on the Physicochemical Properties of Their Constituent Amino Acids. Journal of Theoretical Biology, 267, 29-34. https://doi.org/10.1016/j.jtbi.2010.08.007

[11] Huang, T., Chen, L., Cai, Y.D. and Chou, K.C. (2011) Classification and Analysis of Regulatory Pathways Using Graph Property, Biochemical and Physicochemical Property, and Functional Property. PLoS ONE, 6, e25297.

https://doi.org/10.1371/journal.pone.0025297

[12] Althaus, I.W., Chou, K.C., Franks, K.M., Diebel, M.R., Kezdy, F.J., Romero, D.L., Thomas, R.C., Aristoff, P.A., Tarpley, W.G. and Reusser, F. (1996) The Benzylthio-Pyrididine U-31,355, a Potent Inhibitor of HIV-1 Reverse Transcriptase. Biochemical Pharmacology, 51, 743-750.

https://doi.org/10.1016/0006-2952(95)02390-9

[13] Althaus, I.W., Chou, J.J., Gonzales, A.J., Diebel, M.R., Chou, K.C., Kezdy, F.J., Romero, D.L., Thomas, R.C., Aristoff, P.A., Tarpley, W.G. and Reusser, F. (1994) Kinetic Studies with the Non-Nucleoside Human Immunodeficiency Virus Type-1 Reverse Transcriptase Inhibitor U-90152e. Biochemical Pharmacology, 47, 2017-2028. https://doi.org/10.1016/0006-2952(94)90077-9

[14] Althaus, I.W., Chou, J.J., Gonzales, A.J., Diebel, M.R., Chou, K.C., Kezdy, F.J., Romero, D.L., Aristoff, P.A., Tarpley, W.G. and Reusser, F. (1993) Kinetic Studies with the Nonnucleoside HIV-1 Reverse Transcriptase Inhibitor U-88204E. Biochemistry, 32, 6548-6554. https://doi.org/10.1021/bi00077a008

[15] Althaus, I.W., Gonzales, A.J., Chou, J.J., Diebel, M.R., Chou, K.C., Kezdy, F.J., Romero, D.L., Aristoff, P.A., Tarpley, W.G. and Reusser, F. (1993) The Quinoline U-78036 Is a Potent Inhibitor of HIV-1 Reverse Transcriptase. Journal of Biological Chemistry, 268, 14875-14880.

[16] Chou, K.C., Kezdy, F.J. and Reusser, F. (1994) Review: Kinetics of Processive Nucleic Acid Polymerases and Nucleases. Analytical Biochemistry, 221, 217-230.

https://doi.org/10.1006/abio.1994.1405

[17] Althaus, I.W., Chou, J.J., Gonzales, A.J., Diebel, M.R., Chou, K.C., Kezdy, F.J., Romero, D.L., Aristoff, P.A., Tarpley, W.G. and Reusser, F. (1993) Steady-State Kinetic 
Studies with the Non-Nucleoside HIV-1 Reverse Transcriptase Inhibitor U-87201E. Journal of Biological Chemistry, 268, 6119-6124.

[18] Althaus, I.W., Chou, J.J., Gonzales, A.J., Diebel, M.R., Chou, K.C., Kezdy, F.J., Romero, D.L., Aristoff, P.A., Tarpley, W.G. and Reusser, F. (1994) Steady-State Kinetic Studies with the Polysulfonate U-9843, an HIV Reverse Transcriptase Inhibitor. Cellular and Molecular Life Science (Experientia), 50, 23-28.

https://doi.org/10.1007/BF01992044

[19] Chou, K.C., Chen, N.Y. and Forsen, S. (1981) The Biological Functions of LowFrequency Phonons: 2. Cooperative Effects. Chemica Scripta, 18, 126-132.

[20] Chou, K.C., Li, T.T. and Forsen, S. (1980) The Critical Spherical Shell in Enzymatic Fast Reaction Systems. Biophysical Chemistry, 12, 265-269.

https://doi.org/10.1016/0301-4622(80)80003-2

[21] Chou, K.C. and Forsen, S. (1980) Diffusion-Controlled Effects in Reversible Enzymatic Fast Reaction System: Critical Spherical Shell and Proximity Rate Constants. Biophysical Chemistry, 12, 255-263. https://doi.org/10.1016/0301-4622(80)80002-0

[22] Li, T.T., Chou, K.C. and Forsen, S. (1980) The Flow of Substrate Molecules in Fast Enzyme-Catalyzed Reaction Systems. Chemica Scripta, 16, 192-196.

[23] Chou, K.C. and Forsen, S. (1980) Graphical Rules for Enzyme-Catalyzed Rate Laws. Biochemical Journal, 187, 829-835. https://doi.org/10.1042/bj1870829

[24] Chou, K.C. and Forsen, S. (1981) Graphical Rules of Steady-State Reaction Systems. Canadian Journal of Chemistry, 59, 737-755. https://doi.org/10.1139/v81-107

[25] Chou, K.C., Carter, R.E. and Forsen, S. (1981) A New Graphical Method for Deriving Rate Equations for Complicated Mechanisms. Chemica Scripta, 18, 82-86.

[26] Chou, K.C., Forsen, S. and Zhou, G.Q. (1980) Three Schematic Rules for Deriving Apparent Rate Constants. Chemica Scripta, 16, 109-113.

[27] Chou, K.C. (2015) An Unprecedented Revolution in Medicinal Science. MOL2NET, International Conference on Multidisciplinary Sciences, Vol. 1, 1-10.

[28] Chou, K.C. (2017) An Unprecedented Revolution in Medicinal Chemistry Driven by the Progress of Biological Science. Current Topics in Medicinal Chemistry, 17, 2337-2358. https://doi.org/10.2174/1568026617666170414145508 